\title{
A Scale Development Study to Examine the Application of Total Quality Management
}

\author{
Aytaç AYDIN* Kemal ÜÇÜNC̈̈ \\ Karadeniz Technical University, Department of Forest Industry Engineering Kanuni Campus, Trabzon/Türkiye
}

How to cite: Aydın,A. \& Üçüncï K. (2020). A scale development study to examine the application of total quality management. J. Anatolian Env. and Anim. Sciences, 5(5), 798-801.

Attf yapmak için: Aydın, A. \& Üçüncü K. (2020). Toplam kalite yönetimi uygulamalarının incelemesine yönelik bir ölçek geliştirme çalışması. Anadolu Çev ve Hay. Dergisi, 5(5), 798-801.

* (iD): https://orcid.org/0000-0001-7460-9618 (iD): https://orcid.org/0000-0002-6294-6112
Abstract: The total quality management approach is a management style in which the human factor stands out, continuous development and improvement is adopted, group work is emphasized in the enterprise, and quality responsibility spreads to all of the employees. The goal of total quality management is to provide continuous and excellent service to the customer with well-trained and motivated employees. Within the scope of this study, some feat ures (custo mer orientation, management leadership, full participation, systematic process analysis and human understanding first) of total quality management activities implemented in forest products industry are examined. For this purpose, 377 engineers and foremen working in 14 large-scale companies with ISO 9001 Quality Management System Certificate were reached through a survey method. The questionnaire used consists of two parts. In the first part, some demographic features of the employees were evaluated with 13 questions. In the second part of the survey, the management system applied in the enterprises was researched with 50 questions. The survey data were evaluated with the Structural Equation Model (SEM) prepared in SP SS and AMOS statistical package programs and the results were revealed. As a result, a statistically acceptable scale has been put forward for researchers who want to examine the total quality management studies in the forest products industry.

Keywords: Forest products industry, quality management system, scale development, total quality management.

\section{Toplam Kalite Yönetimi Uygulamalarının İncele mesine Yönelik Bir Ölçek Ge liş tirme Çalış ması}

*Sorumlu yazarın:

Aytaç AYDIN

Karadeniz Teknik Üniversitesi Orman

Fakültesi Orman Endüstri Mühendisliği

Bölümü, Kanuni Kampusü Trabzon, Türkiye

凶: aytac@ktu.edu.tr

Cep telefonu : +90 (505) 2319178

Telef on : $++90(462) 3771513$

Faks $\quad:+90(467) 3757499$
Öz: Toplam kalite yönetimi yaklaşımı, insan faktörünün öne çıktığı, sürekli gelişim ve iyileştirmenin benimsendiği, işletmede grup çalışmasına önem verildiği ve kalite sorumluluğunun tüm çalışanlara yayıldığı bir yönetim tarzıdır. Toplam kalite yönetiminin amacı, iyi eğitimli ve motive olmuş çalışanlarla müşteriye sürekli ve mükemmel hizmet sunmaktır. Bu çalışma kapsamında orman ürünleri sektöründe uygulanan toplam kalite yönetimi faaliyetlerinin bazı özellikleri (müşteri odaklılık, yönetim liderliği, tam katılım, sistematik süreç analizi ve önce insan anlayışı) incelenmiştir. Bu amaçla ISO 9001 Kalite Yönetim Sistemi Belgesine sahip 14 büyük firmada görev yapan 377 mühendis ve ustabaşına anket yöntemi ile ulaşılmıştır. Kullanılan anket iki bölümden oluşmaktadır. İlk bölümde 13 soru ile çalışanların bazı demografik özellikleri değerlenmiş ikinci bölümünde işletmelerde uygulanan yönetim sistemi 50 soruyla araştırılmıştır. Anket verileri SPSS ve AMOS istatistik paket programlarında hazırlanan Yapısal Eşitlik Modeli (SEM) ile değerlendirilmiş ve sonuçlar ortaya çıkarılmıştır. Sonuç olarak, orman ürünleri sektöründe toplam kalite yönetimi çalışmalarını incelemek isteyen araştırmacılar için istatistiksel olarak kabul edilebilir bir ölçek ortaya ko yulmuştur.

Anahtar kelimeler: Toplam kalite yönetimi, ölcek gelistirme, orman ürünleri endüstrisi, kalite yönetim sistemi.

\section{INTRODUCTION}

The unique elements, technologies, production and management processes of the socio-cultural and economic structure, which differ completely from the past, are also changing today, when the environmental conditions change rapidly and the world takes the globalization process. Organizations need to establish an 
effective quality system and management in order to survive in increasingly difficult competition conditions. Today it is the "Total Quality Management" (TQM) model that can provide these (Kaptan, 2007).

TQM is the integration of all functions and processes of an organization to be successful in continuously improving the quality of its goods and services. The goal is customer satisfaction. TQM understanding not only increases the quality but also increases the efficiency of the organization. Employee satisfaction is also taken into consideration in production and service activities that are carried out by considering customer satisfaction (Swift, 1998).

TQM is the art of achieving perfection. It is an effective method to achieve the ideal. Total quality management is the set of principles and philosophy that represent developing organizations. It is quantitative methods and human resources application that improve all processes within the organization. To deliver more than current and future customer expectations. TQM is a discipline carried out with inferential management techniques, existing development efforts and technical tools (Besterfield, 1999).

The basic elements of total quality management, in which the human factor comes to the fore, aims at continuous development and improvement, group work is emphasized in the enterprise, and quality responsibility is in all business employees, are the issues that businesses that adopt the total quality management approach should know. Within the scope of this study, the characteristics of total quality management activities applied in the forest products industry (customer focus, management leadership, full participation, systematic process analys is and human understanding first) are examined and a scale that can be used by researchers who will work in this field is presented.

\section{MATERIALS AND METHOD}

Within the scope of this study, the characteristics of total quality management activities (customer focus, management leadership, full participation, systematic process analysis and human understanding first) applied in the forest products industry were examined. For this purpose, 377 engineers and foremen working in 14 largescale companies holding ISO 9001 Quality Management System Certificate were reached by survey method. In the study, a questionnaire form prepared by compiling from the survey studies applied on TQM and performance was used (Eroğlu, 2003; Serin, 2004; Yağar, 2007; İnce, 2007; Aydın, 2007). The questionnaire used consis ts of two parts. In the first part, some demographic characteristics of the employees were evaluated with 13 questions. In the second part of the questionnaire, the management system applied in businesses was investigated with 50 questions.

The obtained data were checked with reliability and validity analysis. Although there are many models used in reliability analysis, the Cronbach alpha coefficient was used in this study. This coefficient takes values between 0 and 1 (Kalayc1, 2009). In our study, values with $\alpha$ coefficient of 0.80 and above were accepted. In our study, factor analyzes were conducted to measure the construct validity. At this stage, KMO (Kaiser-Meyer-Olkin) and Bartlett tests were applied to determine the suitability of the data for factor analysis.

After determining the suitability of the data for factor analysis, factor analysis was started. Within the scope of the analysis, the principal component factor extraction method and the varimax vertical rotation method were preferred. One of the conditions in the implementation of structural equation models is that each scale should consist of a single dimension and at least 3 variables belonging to that scale should be included in the analys is (Eroğlu, 2003). Within the scope of the study, in order to increase the reliability of the SEM, a limitation has been introduced to be $70 \%$ and above explanatory factor analysis. After these stages, the model prepared was transferred to the AMOS (Analytic Moment of Structure) package program, analyzes were performed and the results were presented.

\section{RESULTS AND DISCUSSION}

General Information of Participants: Some general information about the employees who participated in our survey is given in Table 1 .

Table 1. General information about the participants.

\begin{tabular}{|c|c|c|c|c|c|}
\hline Age & $\mathbf{n}$ & $\%$ & Position in business & $\mathrm{n}$ & $\%$ \\
\hline $20-24$ & 19 & 5,0 & Engineer & 183 & 48,5 \\
\hline $25-29$ & 77 & 20,4 & Foreman & 152 & 40,3 \\
\hline $30-34$ & 85 & 22,5 & Unanswered & 42 & 11,1 \\
\hline $35-39$ & 50 & 13,3 & & & \\
\hline $40-44$ & 22 & 5,8 & Working time in the position & $\mathbf{n}$ & $\%$ \\
\hline $45-49$ & 18 & 4,8 & (years) ${ }^{\circ}$ & & \\
\hline$>50$ & 3 & 0,8 & $0-5$ & 154 & 40,9 \\
\hline \multirow[t]{3}{*}{ Unanswered } & 103 & 27,3 & $6-10$ & 92 & 24,4 \\
\hline & & & $11-20$ & 61 & 16,2 \\
\hline & & & $<21$ & 13 & 3,4 \\
\hline Gender & n. & $\%$ & Unanswered & 57 & 15,1 \\
\hline Male & 301 & 79,8 & & & \\
\hline Female & 42 & 11,1 & Total working time (years) & $\mathbf{n}$ & $\%$ \\
\hline \multirow{3}{*}{ Unanswered } & 34 & 9,0 & & & \\
\hline & & & $0-5$ & 173 & 45,9 \\
\hline & & & 6-10 & 101 & 26,8 \\
\hline Marital status & n. & $\%$ & $11-20$ & 56 & 14,9 \\
\hline married & 200 & 53,1 & $>21$ & 15 & 4,0 \\
\hline Single & 98 & 26,0 & Unanswered & 32 & 8,5 \\
\hline Other & 4 & 1,1 & & & \\
\hline Unanswered & 75 & 19,9 & & & \\
\hline
\end{tabular}

As seen in Table 1, $42.9 \%$ of the employees surveyed are between the ages of $25-35,79.8 \%$ are male, $53.1 \%$ are married. $48.5 \%$ of the participants are engineers and $40.3 \%$ are foremen. $40.9 \%$ of them have been working in this position for a maximum of 5 years. It was 
determined that the maximum working time (45.9\%) was 5 years.

Compliance with normal distribution: Kurtos is values were used to examine the data distribution. The purpose of kurtosis measures is to reveal how the variables are distributed around the mean. If the kurtosis value of the variable is between -3 and +3 , it indicates that the values of the variables come from a typical normal distribution (Kalayc1, 2009). For this purpose, kurtos is values of each variable are given in Table 2.

Table 2. Kurtosis values of the variables.

\begin{tabular}{llllll}
\hline Variables & Kurtosis & Variables & Kurtosis & Variables & Kurtosis \\
\hline co1 & 0,907 & huf1 & $-0,477$ & fp7 & $-1,286$ \\
c02 & 1,374 & huf2 & 0,306 & fp8 & 0,939 \\
c03 & 0,502 & huf3 & $-0,432$ & fp9 & 0,842 \\
c04 & 0,583 & huf4 & 0,189 & fp10 & $-0,147$ \\
c05 & 0,963 & huf5 & $-0,459$ & fp11 & $-0,845$ \\
c06 & 0,206 & huf6 &,- 0615 & fp12 & 0,535 \\
co7 & 0,359 & huf7 & 0,117 & fp13 & 0,762 \\
$\operatorname{co} 8$ & 0,013 & huf8 & $-0,505$ & spa1 & 1,134 \\
co9 & $-0,508$ & huf9 & $-0,180$ & spa2 & 0,390 \\
co10 & $-0,010$ & fp1 & 0,173 & spa3 & 0,390 \\
co11 & 0,694 & fp2 & 0,634 & spa4 & 0,448 \\
co12 & 0,071 & fp3 & 0,390 & spa5 & 0,596 \\
co13 & $-0,024$ & fp4 & 0,211 & spa6 & 0,442 \\
co14 & 0,920 & fp5 & 1,312 & spa7 & 0,365 \\
co15 & 0,421 & fp6 & 1,013 & & \\
\hline
\end{tabular}

As seen in Table 2 kurtosis values of all variables are within the specified limits $(-3 /+3)$. For this reason, it was accepted that the data had a normal distribution and the analys is continued.

Reliability and Validity Analysis: At this stage, the scales were analyzed for reliability and validity, and after obtaining appropriate values, they were subjected to factor analysis. The $\alpha$ coefficient for each scale and the results of factor analysis reduced to a single scale are given in the table.

Table 3. $\alpha$ coefficient for each scale and the results of factor analy sis.

\begin{tabular}{llll}
\hline Scales & Crocbach $\boldsymbol{\alpha}$ & Variables & $\begin{array}{l}\text { Explained } \\
\text { Variance (\%) }\end{array}$ \\
\hline Customer orientation & 91,7 & co4, co6, co7 & 73,372 \\
Human understanding first & 84,4 & huf6, huf8, huf9 & 73,662 \\
Full participation & 87,5 & fp1, fp2, fp3 & 74,402 \\
Sy stematic process analysis & 85,7 & spa2, spa4, spa5, spa6 & 70,735 \\
Management leadership & 89,3 & ml1, ml2, ml3, ml4 & 72,953 \\
\hline
\end{tabular}

Results of the Measurement Model: After the reliability and validity analysis of the scales, the results of the measurement model were examined. The measurement model is shown in Figure 1.

The goodness of fit indexes of the measurement model shown in Figure 1 are shown in Table 4.

As seen in Table 4, the "Chi-square / degree of freedom" of the goodness of fit indices of the measurement model was above the acceptable limit of 2 , therefore a modification was applied to the model. Since the corrected measurement model obtained indexes of goodness of fit are within the limits mentioned earlier, it is accepted that the measurement model is supported by the data.

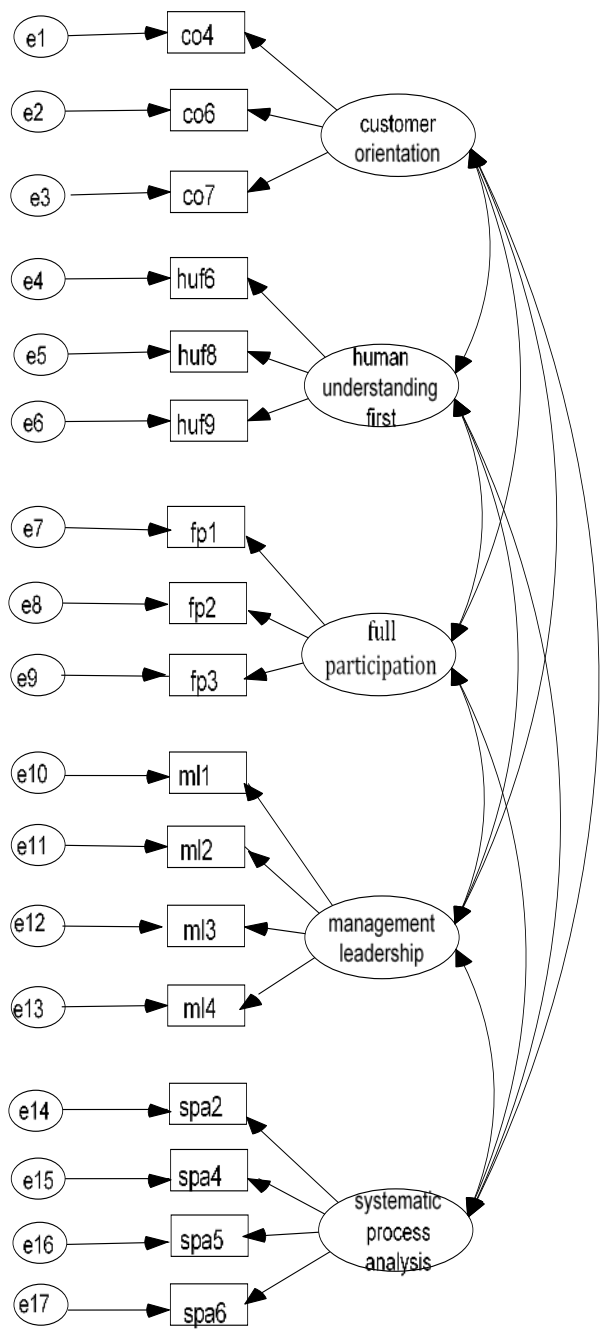

Figure 1. Measurement model.

Table 4. The goodness of fit indexes of the measurement model

\begin{tabular}{lcc}
\hline Fit indexes & $\begin{array}{c}\text { Measurement } \\
\text { model }\end{array}$ & $\begin{array}{c}\text { Adjusted } \\
\text { measurement } \\
\text { model }\end{array}$ \\
\hline Chi-Square statistic & 242,326 & 212,083 \\
Degrees of freedom & 109 & 107 \\
Chi-Square/Degrees of freedom & 2,223 & 1,982 \\
GFI & 0,929 & 0,938 \\
AGFI & 0,901 & 0,911 \\
CFI & 0,964 & 0,972 \\
RMR & 0,034 & 0,033 \\
RMSEA & 0,057 & 0,050 \\
NFI & 0,937 & 0,945 \\
IFI & 0,964 & 0,972 \\
\hline
\end{tabular}

By applying Confirmatory Factor Analysis (CFA) to the improved measurement model, it was revealed to what extent latent variables could be explained by the observed variables. In addition, variance estimates and reliability of the factors calculated in order to determine the validity and reliability of the measurement model are given in Table 5. 
Table 5. CFA results for the improved measurement model.

\begin{tabular}{|c|c|c|c|c|c|c|}
\hline $\begin{array}{l}\text { Latent } \\
\text { Variable }\end{array}$ & $\begin{array}{l}\text { Observed } \\
\text { Variable }\end{array}$ & $\begin{array}{c}\text { Factor } \\
\text { Load }\end{array}$ & $\begin{array}{c}\text { Standard } \\
\text { Error }\end{array}$ & t-value & $\begin{array}{l}\text { Explained } \\
\text { Variance }\end{array}$ & $\overline{\text { Reliability }}$ \\
\hline $\begin{array}{l}\text { Customer } \\
\text { focus }\end{array}$ & $\begin{array}{l}\text { cf } 4 \\
\text { cf6 } \\
\text { cf7 }\end{array}$ & $\begin{array}{l}0,730 \\
0,800 \\
0,794\end{array}$ & $\begin{array}{c}0,060 \\
0,072 \\
-\end{array}$ & $\begin{array}{c}13,746 \\
14,87 \\
7 \\
-\end{array}$ & 0,60 & 0,82 \\
\hline $\begin{array}{l}\text { Human } \\
\text { understanding } \\
\text { first }\end{array}$ & $\begin{array}{l}\text { huf6 } \\
\text { huf8 } \\
\text { huf9 }\end{array}$ & $\begin{array}{l}0,714 \\
0,813 \\
0,813\end{array}$ & $\begin{array}{c}0,070 \\
0,071 \\
-\end{array}$ & $\begin{array}{c}13,78 \\
0 \\
15,51 \\
3 \\
- \\
\end{array}$ & 0,61 & 0,82 \\
\hline $\begin{array}{l}\text { Full } \\
\text { participation }\end{array}$ & $\begin{array}{l}\text { fp1 } \\
\text { fp2 } \\
\text { fp3 }\end{array}$ & $\begin{array}{l}0,737 \\
0,795 \\
0,820\end{array}$ & $\begin{array}{c}- \\
0,071 \\
0,075\end{array}$ & $\begin{array}{c}- \\
14,93 \\
4 \\
15,39 \\
8\end{array}$ & 0,62 & 0,83 \\
\hline $\begin{array}{l}\text { Sy stematic } \\
\text { process } \\
\text { analy sis }\end{array}$ & $\begin{array}{l}\text { spa2 } \\
\text { spa4 } \\
\text { spa5 } \\
\text { spa6 }\end{array}$ & $\begin{array}{l}0,741 \\
0,713 \\
0,782 \\
0,841\end{array}$ & $\begin{array}{c}0,053 \\
0,059 \\
0,056 \\
-\end{array}$ & $\begin{array}{c}15,60 \\
4 \\
14,58 \\
4 \\
16,52 \\
5 \\
-\end{array}$ & 0,59 & 0,85 \\
\hline $\begin{array}{l}\text { Management } \\
\text { leadership }\end{array}$ & $\begin{array}{l}\mathrm{ml1} \\
\mathrm{ml} \\
\mathrm{ml3} \\
\mathrm{ml} 14\end{array}$ & $\begin{array}{l}0,820 \\
0,889 \\
0,744 \\
0,684\end{array}$ & $\begin{array}{c}- \\
0,052 \\
0,055 \\
0,058\end{array}$ & $\begin{array}{c}- \\
20,00 \\
8 \\
16,69 \\
4 \\
14,14 \\
4\end{array}$ & 0,63 & 0,90 \\
\hline
\end{tabular}

Table 5 shows the factor loadings, standard errors, $\mathrm{t}$ values, explained variances and reliability levels of the variables in the measurement model. Considering the factor loads of the variables, it is seen that they change between 0.684 and 0.889 . Therefore, except for $\mathrm{ml} 4$, all other factor loads have values above the critical value of 0.70. In addition, the $t$ values of these predictions were found to be significant at the 0.05 significance level. Therefore, the validity of the measurement model was provided.

In the measurement model, two types of reliability measures were used, namely the explained variance of the factors and the reliability coefficients of the factors. The explained variance estimates of the factors show the total variance value explained by each factor in the relevant observed variables. As seen in Table 5 the explained variance values of the found factors are above the lower limit $(50 \%)$. Reliability coefficients of the factors, another reliability criterion, indicate the internal reliability of the factors. Reliability coefficients of the factors have taken values above the lower limit of 0.70 . Therefore, it can be stated that the measurement model is reliable.

\section{CONCLUSION}

In this study, it is aimed to develop a scale to be used to examine the applications of total quality management in enterprises. The questionnaire form prepared for this purpose was applied in the forest products sector. After the necessary statistical analysis, a scale applicable at sectoral level has been established. Scale developments can be made on different sample groups to examine total quality management practices.

\section{ACKNOWLEDGMENTS}

This research was supported by the Scientific Research Projects Fund of Karadeniz Technical University, Trabzon Turkey; Project no. 113.002.2. This study was presented in ORENKO 2020 held by Karadeniz Technical University, Trabzon.

\section{REFERENCES}

Aydın, S., (2007). The Role of Human Resources in Total Quality Management. Master Thesis. Yeditepe University Institute of Social Sciences. Istanbul.

Besterfield, H.D., (1999). Total Quality Management, Carol Newjersey.

Eroğlu, E, (2003). Analysis of Total Quality Management Applications with Structural Equation Model. $\mathrm{PhD}$ Thesis. İ.Ü. Social Sciences Institute. Istanbul.

İnce, C., (2007). A Research on the Effects of Total Quality Management on Employee Satisfaction in Hotel Businesses in Nevşehir Region. PhD Thes is, C.Ü. Social Sciences Institute. Sivas.

Kalaycı, Ş., (2009). SPSS Applied Multivariate Statistics Techniques. Asil Publication Distribution. ISBN: 975-9091-14-3. Ankara.

Kaptan, K.B., (2007). The Effect of Total Quality Management Applications on the Human Resources of the Organization, Master Thesis, Gazi University, Institute of Social Sciences, Ankara.

Serin, H., (2004). Total Quality Management Doctorate Thesis in Furniture Industry Enterprises in Organized Industrial Zones, KTU Institute of Science, Trabzon.

Swift, J. A., Ross, J. E. \& Omachonu, V. K. (1998). Principles of Total Quality. St. Lucie Pres, Boca Roton, Florida, Second Edition.

Yağar, H., (2007). Relationship between Total Quality Management and Organizational Performance and Financial Sector Practice. Master Thesis. YTU Graduate School of Science, Istanbul. 